Љиљана Бајић

Београдски Универзитет

Филолошки факултет
371.3:: 821.161.1.09(498.11)

https://doi.org/10.18485/filkult.2016.2.ch2

\title{
РУСКА КЊИЖЕВНОСТ У НАСТАВИ КОД СРБА
}

\section{Сажетак}

У раду се даје осврт на руску књижевност у програмима српског језика и књижевности у Републици Србији и на њену рецепцију у наставном контексту. Са методолошког становишта образлажу се компаративна гледишта на руску и српску књижевност у контакту. Истиче се значај поетичких и жанровских елемената и њихова методичка улога у тумачењу дела руске књижевности.

Кључне речи: руска књижевност, рецепција, настава, тумачење

У програме за наставни предмет Српски језик/Српски језик и књижевност у Републици Србији укључен је већи број књижевних дела руских писаца. Чак и летимичан увид у ову област школске наставе показује да су до курикуларне реформе 1991. године и у каснијем периоду актуелних промена у програмима (огледни програми) дела руске књижевности заступљена у знатно већем броју од дела на осталим словенским и другим страним језицима (енглеском, немачком, француском, италијанском, шпанском). Тако руска књижевност у избору класичних дела и писаца Пушкина, Гогоља, Тургењева, Достојевског, Толстоја, Јесењина, Чехова, Ахматове, Мајаковског, Пастернака, Цветајеве, Булгакова, Шолохова, представља значајан, а уз српску књижевност и прворазредни садржај образовања и васпитања ученика, омогућавајући им да стекну знања, вештине и ставове којима могу да се укључе у друштвени, културни и практични живот.

У стварању методичких пројеката за рад на програмским делима руске књижевности не губи се из вида да је њихова наставна 
рецепција обично посредована преношењем књижевног текста са руског на српски језик, као и да је тиме условљена рецепција текста "отежана" у мери у којој се оригинал разликује од (варијаната) превода. Зато се у школи намеће потреба да се изворни текст, када год је то могуће, доводи у поредбени однос са преведеним текстом и на тај начин појача његово примање и деловање на читаоца.

За наставу књижевности поредбени поступак методички је функционалан и онда када се дела руске и српске књижевности посматрају као потенцијални поредбени релати (Гогољ и Нушић, Достојевски и Станковић и други примери). Упоредно истраживање њихових сличности, аналогија и утицаја обавља се са циљем да се књижевна дела приближе једна другима или другим видовима уметности, културе и знања, те да се чињенице и текстови раздвојени језиком дубље доживе и кроз интертекстуални однос потпуније схвате њихови традицијски, религијски, етички и естетички елементи.

У литератури је познато да је Гогољ био подстицај за комедиографска остварења Бранислава Нушића писана осамдесетих година 19. века, Народни посланик, Протекција, а на првом месту Сумњиво лице. Талас ове литерарне везе дошао је заједно са јачањем утицаја руске књижевности на српску књижевност, у којој је Гогољево присуство знатно дуже од столећа. Превођење Гогољевих дела и њихово извођење на позоришној сцени, као и прилози о писцу и делу усрпској штампи, посебно од 70-тих година 19. века, када је, како сматра Јован Скерлић, пишчев утицај на српску књижевност био нарочито велики, омогућили су Гогољев вишеструки уплив у културни и књижевни живот код Срба. Живу рецепцију Гогољевог дела у нашој култури тога доба илуструје, на пример, податак да су Милован Глишић и Лаза Лазаревић своју књижевну делатност започели преводећи 1870. године, још као ђаци Велике школе, по једну Гогољеву приповетку (Милица Милидраговић, у необјављеној дисертацији Гогољ код Срба, наводи да је Лазаревић превео приповетку Ђаволска посла, а Глишић приповетку Иван Фјодорович Шпоњка и његова mem$к a)$, али и чињеница да се трагови Гогољевог утицаја опажају на само у Нушићевом делу већ и у делима више писаца тога времена, М. Глишића, Ј. Веселиновића, С. Ранковића, И. Вукићевића, Ј. Игњатовића, С. Сремца, Р. Домановића. 
Методолошки основ поредбеног проучавања књижевних дела у настави, у том смислу и упоредно тумачење комедиографског дела Гогоља и Нушића, усклађује се са школским контекстом који је уређен према дидактичким принципима из три основне групе чинилаца, школског градива/програма, психологије учења и наставних циљева. Корелација књижевних предмета и појава има у настави своје методолошко упориште у тематолошким, поетичким, књижевноисторијским и књижевнотеоријским чињеницама, које омогућавају да се као приоритетни остварују циљеви у области језичких и књижевних компетенција. Корелативно становиште успоставља се према појединачним појавама које улазе у сферу утицаја и прожимања, као и према подручјима којима те појаве припадају. У такав корелативни методички наставни систем укључује се и компаративно изучавање дела Гогоља и Нушића, комедија Ревизор и Сумњиво лице, па се у синхроној поставци анализирају њихови књижевни и сценски елементи. Начело корелације овде је повезано и са схватањем драмског текста као посебне форме књижевног дискурса, специфичне по томе што садржи „текстуалну матрицу представљачког”, односно, „иманентну театралност" (Miočinović 1981: 40). Отуда потиче и његова сложеност, посебан начин артикулације његових значења и ширина поља испитивања када он постане предмет тумачења. Из односа драме и позоришта развила се методичка теорија о литерарном и театролошком приступу драмском делу, о синхроности бинарних гледишта на драму као књижевну и сценску уметност. Та теорија пружила нам је основне смернице у литерарном и сценском читању комедиографских дела Ревизор и Сумњиво лище.

У савременој настави Гогољево дело представља истраживачки изазов за читаоца који у њему налази стваралачку синтезу више елемената: реалистичких (на плану тематике и ликова), сатиричних и креатуралних (који се остварују превођењем животних појава на материјално-телесни план и њиховим снижавањем у ниско и ништавно), гротескних и фантастичних елемената (који се откривају како у врстама комике и смеха, тако и у необичним и зачуђујућим појавама, каква је Жандарова на крају комедије). Да би се одговорило овом изазову, неопходно је сазнајни процес у настави уздићи на раван критичког (проблемског) мишљења. Тада се могу поставити литерарна питања као што су следећа: 
- Реалистички елементи слике друштва и губернијског чиновништва у Русији 19. века

- Реалност и привид у комедији Ревизор

- Креатурално и гротескно изобличавање корупције, мита и друштвеног устројства превођењем типичног у осредње и ништавно

- Смехотворни поступци у Гогољевој комедиографији

- Врсте смеха у појавама ружног, настраног и ниског у комедији

- Гогољ и српска књижевност реализма

- Гогољ и хумористичка и сатирична књижевност код Срба

- Гогољ и Нушић: тематика, комични поступак и драматуршки елементи у комедији Ревизор и Сумњиво лице

- Ревизор на позоришној сцени

- Озбиљно и комично у комедији Ревизор и њеној сценској реализацији

- Позиција читаоца и позиција гледаоца комедије Ревизор: виђење предмета из другог угла; наставно и сценско тумачење комедије као продужетак читалачког чина

Увид у литерарне проблеме саставни је део наставног тумачења Гогољевог дела. У сазнајном процесу они су претходница истраживачког рада, која покреће стваралачко мишљење и омогућава читаоцу да понире у свет Гогољевог дела и његову реализацију на сцени. На пример, тумачење смехотворних поступака у Гогољевој комедији водиће ка уочавању и анализи њихових бројних облика и врста. Из тог каталога издвајамо следеће: комику сличности и дублирања ликова (Бопчински и Допчински) која проистиче из њихове близаначке аморфности, из забуне коју они могу да произведу и алузије на њихову безличност; истицање човековог физичког бића, посебно дебљине и физиолошких функција тела (облапорност и халапљивост Хљестакова); опредмећивање и обесмишљавање актера комедије као механичке масе на сцени, хибридизација њеног живота и окамењеност на крају комада; исмевање и изругивање намерама и поступцима ликова градоначелника, чиновника и спахија; комично преувеличавање бесмислица и лажи тобожњег ревизора, комика гестова и изражајног понашања (упадица, сударања, замуцкивања, снебивања, скривања, 
падања актера на сцени у напетим ситуацијама). Импулс комичној радњи у Ревизору дају комичне ситуације које су засноване на забуни градских чиновника у погледу Хљестакова и на превари Хљестакова који ту забуну користи. Сликајући ружно и настрано у друштвеном поретку тога времена и померајући реалност ка хиперболи и гротески која га изобличава, Гогољ је своју комедиографску вештину усмерио ка томе да и читаоца придобије да се сложи са писцем о непожељности оног што је предмет смеха.

О Гогољевом утицају на Нушића код нас се расправљало у више наврата. Не налазећи истоветност између руске бирократије тридесетих година 19. века и српске бирократије за време Милана Обреновића, за које се везује Нушићево Сумњиво лице, Лав Захаров закључује да не постоји „унутрашња сличност” два комада и да је Нушић теми пришао са „властитим мерилом” (Zaharov 1951: 117). За Владимира Петрића утицај Гогоља на Нушића омогућио је српском писцу да помоћу преузетих поступака створи оригиналне комичне ситуације (Petrić 1965: 146). Слично мишљење има Јосип Лешић. Налазећи да је Гогољ помогао Нушићу да савлада драмску технику, Лешић сматра да је српски писац помоћу ње створио оригиналну комедиографију (Lešić 1981: 21). Не улазећи у анализу тог утицаја, закључићемо да се према Гогољевим литерарним и драматуршким поступцима Нушић није односио као према позајмицама које је подражавао, већ као према подстицајима који су дали оригиналне резултате.

Извор комике у Ревизору и Сумњивом лицу чине појаве под маском великог и важног, које се показују као ниске и ништавне. Као код Гогоља, и у Сумњивом лицу драмска радња компликује се захваљујући заблуди, замени Хљестакова за ревизора, односно апотекарског помоћника за сумњиво лице које носи антидинастичке списе, код Нушића. Осим на тематском, између комедија постоји сличност и на мотивском плану. На пример, у оба дела важан је мотив писма које је отворено пре него што је стигло до адресата. Али овај мотив у Нушићевом делу нема функцију покретача заплета, као у $P e-$ визору, већ добија истакнуто место у оригиналној драмској линији љубавног конфликта који је развијен у Сумњивом лицу. Материјал за комедију, како је писао Нушић, пружила му је бирократија, која 
код свих народа има опште и вечите елементе. Њој је писац скидао маске и откривао лице помућу хумористичког смеха. Нушићев смех је, не претендујући на дидактичност, претресао бирократску нарав и институције власти. Његова комедиографија, једним делом отворена за карикирање, односно предимензионирање комичног несклада, извориште смеха налази у комичним поступцима заснованим на контрасту између жеља и способности драмских актера и нескладу између циљева и средстава којима се до циљева долази. Илустративан је пример капетана Јеротија Пантића: порочан је и кукавица, али пред министром би хтео да се покаже као извршилац јуначког дела; циљ му је да добије вишу класу, али да би мога да дође до ње служи се лажима; неваљалство писара Виће оцењује као способност и изузетност јер овај зарађује на династији, „музе државу”. Други извор Нушићевог смеха је вербална комика. Путем вербалне комике испољавају се драмски карактери и менталитет запарложене средине, за шта се користе поступци мешања говорних стилова, омашке, алогизми, игре речима, као у примеру депеше о „кљуканој династији”, или у примеру писама које Јеротије погрешно схвата јер не зна да га пишу његова заљубљена ћерка и апотекарски помођник Ђока.

Интересовање за комедије Гогоља и Нушића у савременој настави може се објаснити присуством и виталношћу смеха у њима. У поетичком систему оба писца смех, реакција на мане друштва и појединца, открива непривлачно лице комичног предмета, али, жигошући га, има особину да га поправља. У Гогољевој комедиографији смех добија значај већи него што је разонода и забава људи. Зато је писцу било жао што у Ревизору није запажено да постоји, као је писао, поштено и племенито лице смеха. Оно, сматра Гогољ, извире из „светле природе човекове" (Lešić 1981: 6), а његова прозирућа снага помаже да предмети које обухвати постану дубљи и да се виде боље. Са друге стране, за Нушића, чак и када је по сопственим речима писао брзо и небрижљиво, хумор се није могао делити на тежак и лак јер је само један и јединствен, „онај који изазивајући смех на уснама ублажава суровост живота". Гогољ и Нушић имају слично схватање о функцији смеха: смех поправља и катарзички прочишћава људе. Зато бисмо, парафразирајући Бергсона, закључили да је код оба писца смеху потребна јека, односно одјек до кога долази у интеракцији са читаоцем. Тада савремени читалац прихвата писце као своје сабеседнике. 
О значају дела руских писаца у програмима говори податак да су она у обавезном и допунском избору предвиђена за наставну обраду у основној и средњој школи, као и да је стваралаштво једног броја писаца, и то: Пушкина, Толстоја, Јесењина и Чехова, представљено у ширем избору њихових репрезентативних дела ${ }^{1}$. Посебно је илустративна чињеница да је Чехов са новелама Шала, Вањка, Чиновникова смрт, Туга и драмом Ујка Вања, изузев у седмом разреду основне школе, заступљен у свим осталим разредима на оба нивоа наставе. Овакав програмски контекст појачава доживљајну и искуствену мотивацију за читање и тумачење Чеховљевих дела, омогућавајући да се њихова обрада усагласи са поетичким и жанровским елементима и да се тако дата дела опсежније и интензивније изуче.

У примању и деловању Чеховљевих дела у настави жанровски појмови и очекивања која се са делима повезују имају сазнајну и мотивациону улогу. Они помажу да ученик боље разуме појединости у делу јер са изабраним примерима новела Шала, Туга, Вањка, Чиновникова смрт и драме Ујка Вања повезује одређене жанровске елементе и особине које прате таква дела. Треба нагласити да је приликом наставне обраде Чеховљевих књижевних остварења жанровски контекст релевантан онолико колико и/или како је у тексту интегрисан. У околностима поузданог сазнавања уз помоћ корисних оријентира жанра ученик може доћи до бољег разумевања и поимања дела онда када Чеховљево приповедачко умеће открива, на пример, путем анализе експресивних чинилаца у новелама Шала и Туга. Занимљив предмет истраживања у настави чине наслови ових новела, који наговештавају жанровско окретање ка тематици из свакодневице и ка доживљајима јунака. У аналитичко-синтетичком раду на Чеховљевим делима, у коме су наслови подигнути на ниво литерарних проблема чије решавање омогућава дубље доживљавање и адекватније тумачење дела, посебно се истражују и тумаче следећи проблеми: облик, значење и функција насловног мотива у уметничком свету дела; однос наслова, фабуле и сижеа новеле, као и наслова и врсте мотивације, посебно композицијске и

1 Реч је о песмама Волео сам Вас А. С. Пушкина и његовим поемама Евгеније Оњегин и Цигани, о тексту Девојчица и крчаг и романима Pam и мир и Ана Карењина Л. Н. Толстоја, као и о песмама Бреза, Песма о керуши и Писмо мајци С. Јесењина. 
естетичке мотивације у новели; условљеност наслова стваралачком стратегијом и поступцима у делу; однос текста и читаоца/ученика који га прима саображено са својим књижевним искуством, животном праксом, интересовањем и ставовима.

Када је у питању драма Ујка Вања, у настави се овом делу прилази као особеном и препознатљивом за такозвано чеховљевско позориште. Дело нема класичну драмску радњу и оштро издвојене драматичне догађаје већ је уроњено у свакодневицу збивања у којој се сударају узвишено и тривијално, озбиљно и банално. Зато се одговарајуће литерарно и театролошко читање/тумачење ове драме усклађује са њеним лирским, поетским и психолошким особитостима, са посебним ритмом и темпом у дијалозима, али и у паузама, те усмеравањем ученика на анализу стања јунака и на посебан сценски језик комада.

у овоме раду улога жанровских елемената у тумачењу књижевног дела А. П. Чехова образлаже се на примеру новеле Шала.

Шала је интересантан али и загонетан књижевни текст, што се може илустровати следећим одломком:

Некако пред одлазак, на два дана седим у сумраку у баштици, а од дворишта, у коме станује Нађењка, та баштица је одвојена високом оградом са гвозденим шиљцима... Још је прилично хладно, на ђубрету има још снега, дрвеће је мртво, али већ мирише на пролеће и, спремајући се на починак, живо гракћу грачци. Ја прилазим огради и дуго гледам кроз шупљину. Ја видим како Нађењка излази на степенице и управља тужан, очајнички поглед у небо... Пролећни ветар јој дува право у бледо, сетно лице... Он је подсећа на онај ветар који нам је хујао онда на брегу кад је она слушала оне четири речи, и лице јој постаје жалосно, жалосно, низ образе ће потећи сузе... И сирота девојчица пружа обе руке, као да моли тај ветар да јој донесе још једном оне речи. И ја, сачекавши ветар, изговарам полугласно:

- Ја вас волим, Нађа!

Боже мој, шта ли се збива са Нађенком! Она кличе, смешка се целим лицем и пружа руке у сусрет ветру, радосна, срећна, необично дивна.

А ја идем да се пакујем...

Давно је то било. Сад је Нађењка већ удата; удали су је, или је сама пошла... свеједно, за секретара племићког 
масалног фонда и сад већ има троје деце. Оно како смо ја и она некад ишли на санкање и како је ветар доносио до ње речи „Ја вас волим, Нађењка“, није заборављено; за њу је то сада најсрећнија, најнежнија, и најлепша успомена у животу...

И мени сад, кад сам постао старији, није више јасно зашто сам изговарао оне речи, зашто сам се шалио...

(Чехов 1981: 78)

Основано је претпоставити да ће дело, на чијем се крају и сам приповедач пита зашто је изговарао празне речи о љубави, изазвати недоумице и запитаност код читалаца. На пример, они се могу суочити са питањима: О каквој је шали овде реч? Какво значење изговорене речи о љубави имају за приповедача, а какво за јунакињу? Да ли им је она приписала непостојећи смисао? Шта је у Шали духовито и безазлено, а шта озбиљно? И слично.

Да би уживао у причи, читалац треба да се саживи са њеном хумористичком интенцијом, која је наговештена у наслову, и у поигравању приповедача са јунакињом. Хуморни потенцијал Шале заснива се на понављању (дублирању) наративне секвенце санкања и вербалне формуле „Ја вас волим, Нађенка“, којом се приповедач поиграва са јунакињом. Пошто је комично највише ослоњено на шалу путем више-мање празних речи о љубави, његов ефекат може се упоредити са ефектом лажи која је постала смешна. Али свака лаж није комична. Према тумачењу В. Пропа, да би лаж постала смешна, она мора да испуни два услова: прво, треба да буде ситна и да не изазива трагичне последице, и друго, мора бити разобличена јер неразоткривена лаж није комична (Проп 1984: 102). Оба услова у причи су испуњена: са једне стране, шала није озбиљно утицала на јунакињу, а са друге стране, читаоцу је од почетка до краја приче пружена могућност да увиди и разоткрије приповедачеву игру са јунакињом, прозирући њену шаљиву суштину.

За разлику од сарказма и злурадости, који су присутни у другом типу смеха, какав је, на пример, сатирични смех, у новели Шала ради се о безазленом и доброћудном смеху. Приповедачево поигравање са Нађом и њена љубопитљивост и бојажљивост, за коју приповедач једном каже да је кукавичлук, а други пут да је малодушност, могу да буду предмет благонаклоног смеха зато што немају карактер порока 
већ ситних недостатка, који, као такви, код читаоца изазивају симпатију за јунаке и осмех разумевања и прихватања. Јер, када се посматрају на општем плану одобравања и оспоравања, мали недостаци не само што се не доживљавају као негативни већ могу и да појачају читаочево осећање симпатије за јунаке, којима прашта њихове недостатке. То је психолошка основа доброћудног смеха (Проп 1984: 138).

На примеру Чеховљевог дела може се извести следећи закључак: да би се уживео у хумористички потенцијал текста, читалац треба да се саживи са стваралачком стратегијом и поступцима у делу. Ако своје становиште усагласи са хуморним становиштем текста, биће награђен доживљајем ведрине и веселости, који се доводи у везу са афективним реаговањем на потенцијално шаљиве елементе у уметничком свету дела. Али ако запажајући сетну озбиљност теме не уочи/уважи хумористичке поступке, може се десити да Шалу чита и као озбиљну причу, на пример, као причу која тематизује изневерену љубав, или приповедачеву љубавну превртљивост и у том контексту наслов приче схвати као аутоироничан, услед чега ће комични утисак тада бити доведен у питање или изостати. Другим речима, сам текст показује тумачима различите смернице које се повезују са његовом жанровском пропустљивошћу и поливалентношћу. Прихватајући сигнале, податке за рецепцију, које прича пружа, читалац у њих уноси разумевање саображено са својим књижевним искуством, животном праксом, интересовањима и ставовима. Начин како се видокруг и ставови читаоца повезују са видокругом дела утицаће на резултате читања и сазнавања Чеховљевог дела у настави.

\section{Литература}

Гогољ 1970: Н. В. Гогољ, Драмска дела, Београд: Народна књига, Цетиње: Обод. Zaharov 1951: L. Zaharov, Gogolj i Nušić, Beograd: Književnost.

Lešić 1981: J. Lešić, Nušićev smijeh, Beograd: Nolit.

Miočinović 1981: M. Miočinović, Moderna teorija drame, Beograd: Nolit.

Нушић 1966: Б. Нушић, Сумњиво лице, Хајдуци, Београд: Издавачко предузеће Јеж.

Petrić 1965: V. Petrić, Osobenosti smešnog u Nušićevim komedijama, Beograd: Zavod za udžbenike SR Srbije.

Проп 1984: В. Проп, Проблеми комике и смеха, Нови Сад.

Чехов 1981: А. П. Чехов, Приповетке, Београд: Просвета, Нолит, Завод за уџбенике и наставна средства. 
Ljiljana Bajić

University of Belgrade

Faculty of Philology

\section{RUSSIAN LITERATURE IN TEACHING}

\section{AMONG THE SERBS}

The paper provides an overview of Russian literature in the programs of the Serbian language and literature in the Republic of Serbia and its reception in the educational context. Comparative views of the Russian and Serbian literature in contact are explained from the methodological point of view. The importance of poetic and genre elements and their methodical role in the interpretation of the works of Russian literature are emphasized.

Key words: Russian literature, reception, teaching, interpretation 